\title{
Southeast Asia's import demand for skim milk powder: Implications for US exporters
}

\author{
C. G. Davis,${ }^{* 1}$ J. G. Cessna, ${ }^{*}$ and D. P. Blayney† \\ *Market and Trade Economics Division, Economic Research Service, USDA, 355 E Street, SW, Washington, DC 20024 \\ †Department of Agricultural Economics and Agricultural Business, New Mexico State University, PO Box 30003, Las Cruces 88003
}

\begin{abstract}
Dairy industries in Southeast Asia are small and produce less than the domestic market demands. As expenditure and population grow in Southeast Asia, it is expected that the expenditures on skim milk powder (SMP) will grow. In this study, we examined the competitiveness of US SMP in the Southeast Asian market with respect to other leading dairy exporters, including the European Union (EU-28), New Zealand, and Australia. Using monthly data from 2006 to 2015, Rotterdam models were used to estimate import demands for SMP in 4 Southeast Asian countries. In a scenario using annual averages from 2013 to 2015 as a baseline, our findings suggest that a $10 \%$ reduction in the US price of SMP would cause Indonesia, Singapore, Vietnam, and the Philippines SMP imports from the United States to increase by 3.96, 0.44, 2.68, and 1.94 kt, respectively. Under the same scenario, the value of US SMP imports would decrease for Indonesia, Vietnam, and the Philippines by $\$ 4.12, \$ 2.93$, and $\$ 2.48$ million, respectively; however, the value of US SMP to Singapore would increase by $\$ 0.20$ million. Singapore and Indonesia expenditures for the US SMP are elastic, which means that as expenditure and population in Southeast Asia continue to grow, a 1\% increase in SMP expenditure in Singapore and Indonesia would result in 1.25 and $1.20 \%$ increases in US SMP exports.
\end{abstract}

Key words: skim milk powder, import demand, trade, competitiveness, Southeast Asia

\section{INTRODUCTION}

Skim milk powder [SMP; refers collectively to nonfat dry milk (NDM) and skim milk powder except as otherwise stated] was the top dairy product by value imported by Southeast Asia [defined by the USDA Eco-

Received March 8, 2017.

Accepted December 14, 2017.

${ }^{1}$ Corresponding author: chrisdavis@ers.usda.gov nomic Research Service as Burma (Myanmar), Brunei, Cambodia, Indonesia, Laos, Malaysia, Philippines, Thailand, Vietnam, and Singapore] in 2015, totaling $\$ 1.6$ billion, almost $30 \%$ of the region's total dairy import value. [Note: import values throughout this paper are from the Global Trade Atlas (2016; https://www .gtis.com/gta/); those discussed in the introduction include imports for Indonesia, Malaysia, Philippines, Thailand, and Singapore. Burma (Myanmar), Brunei, Cambodia, Laos, and Vietnam do not report dairy import values to Global Trade Atlas; therefore, export data from their trading partners are used. Data for trade within the Southeast region (e.g., from Singapore to Vietnam) are included in the totals.] Adjusted for inflation, the value of SMP imports grew by $62 \%$ over the decade from 2006 to 2015 (Global Trade Atlas, 2016). The top exporters of SMP to the region in 2015, ranked by import value, were New Zealand, the European Union (EU; specifically the EU-28, even though some of the countries were not members of the EU during part of the period studied), the United States (US), and Australia. In 2006, the same 4 suppliers were at the top of the list but the rank order was different: New Zealand > Australia > US > EU (Table 1).

Southeast Asian countries with significant imports of SMP in 2015 included the Philippines, Indonesia, Malaysia, Singapore, Thailand, and Vietnam. For all of these countries except Singapore, SMP was the top imported dairy product by value; for Singapore, SMP was second after whole milk powder (Global Trade Atlas, 2016). Although all of these countries had significant imports of SMP, market share among suppliers differed substantially from one country to another. For example, the US was the top supplier of SMP to the Philippines, accounting for $35 \%$ of the import share (Global Trade Atlas, 2016). At the other end of the spectrum, Singapore's SMP imports from the US made up only $5 \%$ of Singapore's total SMP import value (Global Trade Atlas, 2016).

Undoubtedly, price plays an important role in the decision making of SMP importers. Imports among all of the countries are expected to be inversely related to 
Table 1. Southeast Asia dairy product import values by trading partner and product in 2015 and 2006 (in millions of constant 2015 US dollars) ${ }^{1}$

\begin{tabular}{|c|c|c|c|c|c|c|c|}
\hline Year/trading partner & $\mathrm{SMP}^{2}$ & $\mathrm{WMP}^{3}$ & $\begin{array}{l}\text { Infant } \\
\text { formula }^{4}\end{array}$ & $\begin{array}{l}\text { Butter and } \\
\text { butterfat products }\end{array}$ & $\begin{array}{l}\text { Other dairy } \\
\text { products }\end{array}$ & $\begin{array}{l}\text { Value per } \\
\text { trading partner }\end{array}$ & $\begin{array}{l}\text { Percent per } \\
\text { trading partner }\end{array}$ \\
\hline \multicolumn{8}{|l|}{2015} \\
\hline United States & 365.9 & 47.7 & 3.0 & 139.5 & 173.0 & 729.2 & 12.9 \\
\hline Australia & 295.4 & 52.0 & 13.0 & 27.6 & 257.0 & 645.1 & 11.4 \\
\hline Rest of world & 48.4 & 65.0 & 440.3 & 55.1 & 439.8 & $1,048.6$ & 18.6 \\
\hline New Zealand & 396.4 & 345.2 & 16.5 & 102.2 & 198.7 & $1,058.9$ & 29.4 \\
\hline EU-28 & 97.2 & 111.5 & 132.0 & 51.3 & 290.4 & 682.4 & 18.9 \\
\hline United States & 224.0 & 16.9 & 0.4 & 0.8 & 136.3 & 378.5 & 10.5 \\
\hline Australia & 260.1 & 189.5 & 24.8 & 54.1 & 221.4 & 749.9 & 20.8 \\
\hline Rest of world & 36.3 & 230.7 & 164.2 & 11.0 & 293.2 & 735.4 & 20.4 \\
\hline Value per product & $1,014.0$ & 893.8 & 337.9 & 219.5 & $1,140.0$ & $3,605.1$ & 100.0 \\
\hline
\end{tabular}

${ }^{1}$ Source: Global Trade Atlas (2016; https://www.gtis.com/gta/).

${ }^{2} \mathrm{SMP}$ (skim milk powder) includes products exported under Harmonized Schedule (HS) number 040210.

${ }^{3} \mathrm{WMP}$ (whole milk powder) includes products exported under HS numbers 040221 and 040229.

${ }^{4}$ Infant formula includes products exported under HS number 190110.

${ }^{5}$ Butter and butterfat products include products exported under HS number 0405.

the general global price level of SMP. Relationships between prices from one country to another are expected to have effects on the proportions of SMP imported from each country. However, other factors play significant roles as well, including tariffs, nontariff trade barriers, product quality, proximity, and existing business relationships.

This report qualitatively examines trends in SMP imports for 4 Southeast Asian countries: the Philippines, Indonesia, Singapore, and Vietnam. These countries represent 4 of the largest importers of SMP in Southeast Asia. (Other Southeast Asian countries were considered, but Thailand, Myanmar, Brunei, Cambodia, and Laos had very small SMP import volumes or several months of no trade, whereas Malaysia's SMP import demand results did not satisfy basis demand theory.) The US's SMP faces significant competition from other exporting countries. Our analysis takes a closer quantitative look at SMP imports and quantifies each country's sensitivity to prices of the 4 leading global SMP suppliers to the region (New Zealand, the EU, the US, and Australia). The objective of this study was to estimate each of the selected country's import demands for SMP from each major supplier in terms of responsiveness to changes in prices and total expenditures for SMP. Two types of price responses are examined in this study: (1) own-price elasticity, and (2) cross-price elasticity. Own-price elasticity measures the importer's responsiveness to a percentage change in the quantity demanded of SMP due to a percentage change in the exporters' SMP price. Meanwhile, cross-price elasticity measures a percentage change in SMP import quantity from a particular country corresponding to a percentage change in the export price of another country. Expenditure elasticity measures the exporters' change in quantity of SMP exported to the importing country corresponding to a percentage change in total import expenditures of SMP by the importing country. Using monthly data from the decade of 2006 through 2015, a separate Rotterdam model (Barten, 1964; Theil, 1965) was constructed for each Southeast Asia importing country to quantify expected changes in SMP imports in response to average price changes for all 4 exporting countries combined and changes in prices of each exporting country relative to the others.

\section{DESCRIPTION OF SMP IMPORTS FOR SELECTED COUNTRIES}

Figures 1, 2, 3, and 4 display the evolution of SMP imports for the 4 importing countries analyzed in this report (Indonesia, Singapore, Vietnam, and the Philippines) from the 4 major suppliers (EU, New Zealand, Australia, and the US). The US has been a major player in all of the countries' SMP markets except for Singapore; for all countries except Singapore, there has been an upward trend in imports of SMP from the US. For the EU, there has been an upward trend in SMP exports for every country. For Australia, trends have been mixed, with only Indonesia showing a clear upward trend. Imports for New Zealand have no clearly discernible trend except for a downward trend for the 


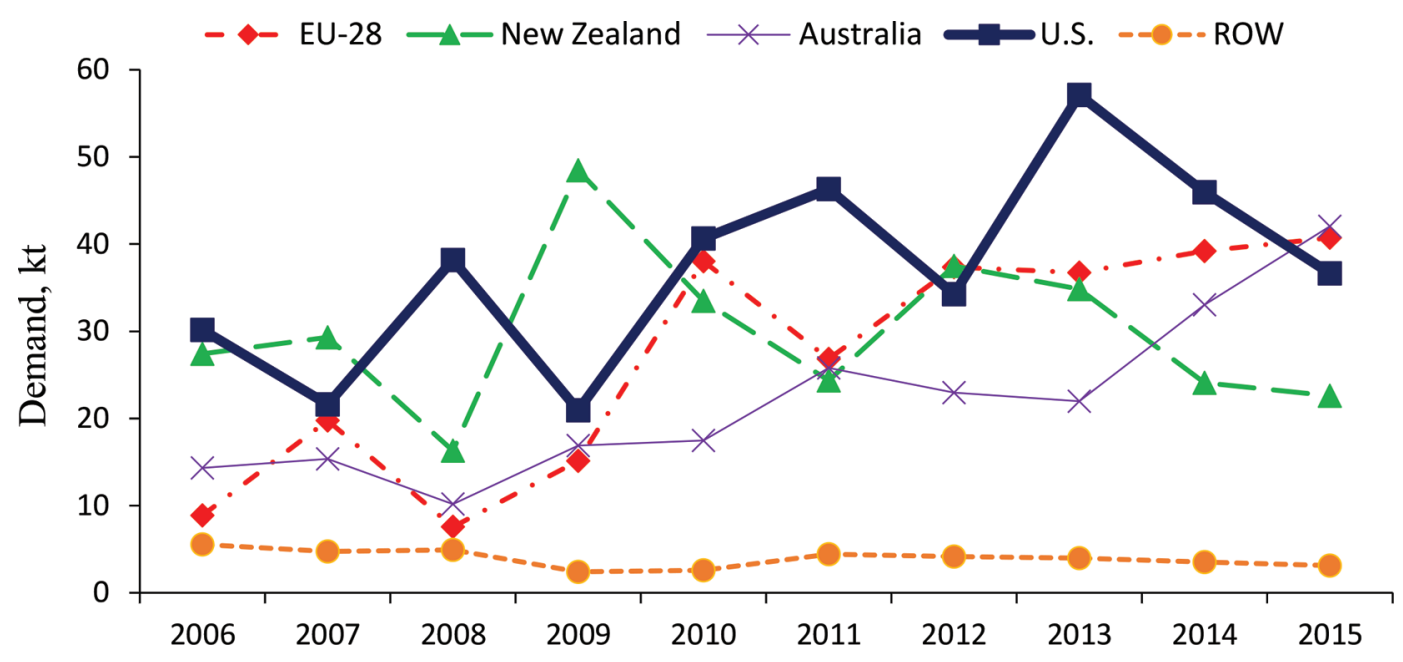

Figure 1. Indonesia's import demand (kilotonnes) for skim milk powder from major suppliers. ROW = rest of world. Source: Global Trade Atlas. Color version available online.

Philippines. Although New Zealand has been competitive with other suppliers for all of the countries, it is notable that it has been the top supplier to Singapore throughout the study period.

From 2006 to 2015, Indonesia's combined import volume of SMP increased by $76 \%$ among the 4 major suppliers. Figure 1 shows that imports from EU, Australia, and the US increased by 358, 193, and 21\%, respectively, over the 10-yr period. In 2013 and 2014, the US was the largest supplier of SMP to Indonesia, followed by the EU. In 2015, the US share dropped to third, behind Australia and the EU.

From 2006 to 2015, the US exported only $34 \mathrm{kt}$ of SMP to Singapore over the entire period (Figure 2). Although New Zealand has consistently been the larg- est supplier of SMP to Singapore, the market share has grown the most for EU imports of SMP, a 5-fold increase from 2006 to 2015. New Zealand had relatively moderate growth (26\%), whereas exports of SMP from Australia and the US to Singapore declined 30 and $22 \%$, respectively, over the $10 \mathrm{yr}$.

As per capita income grew in Vietnam from 2006 to 2015, Vietnam's SMP imports increased 147\% (Figure 3 ). Imports of SMP from each of the major suppliers to Vietnam increased by more than $100 \%$. Vietnam's imports from the US increased by $110 \%$, and the US was Vietnam's largest supplier followed by EU, New Zealand, and Australia. Over the 10-yr period, the US accounted for more than $45 \%$ of the total SMP supplied to the Vietnamese market by top dairy exporters.

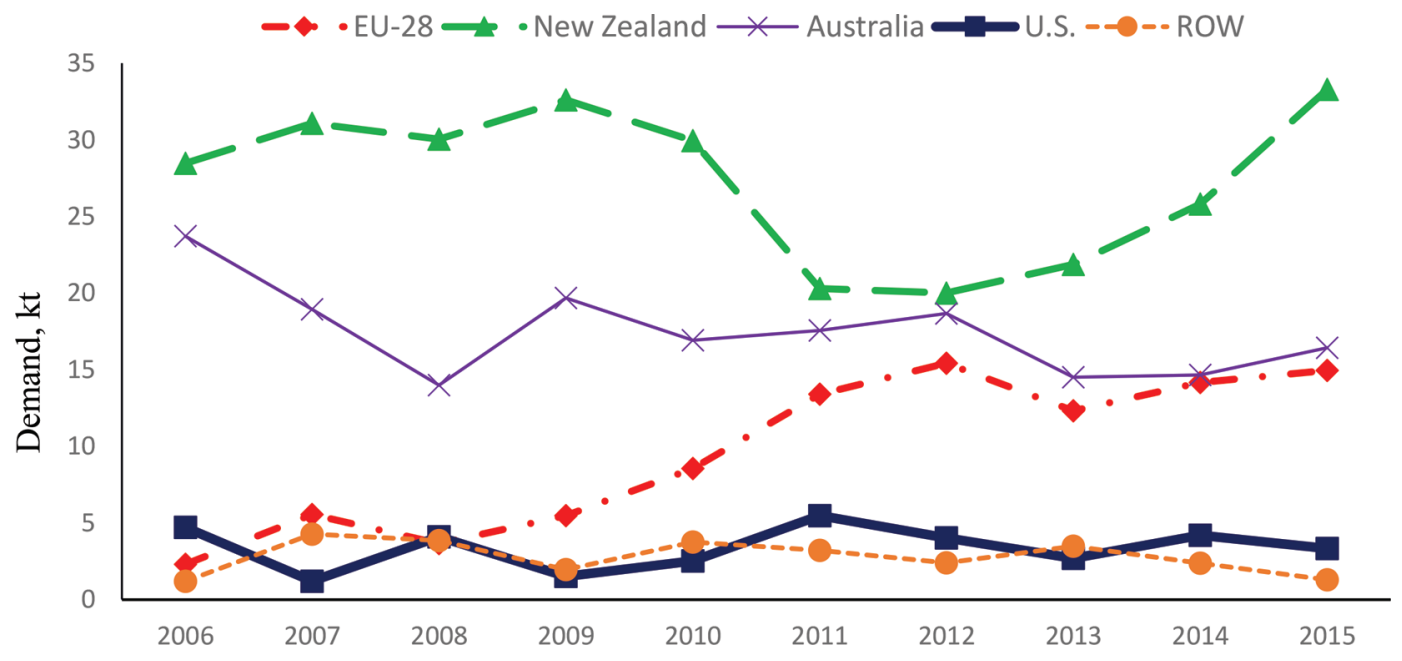

Figure 2. Singapore's import demand (kilotonnes) for skim milk powder from major suppliers. ROW = rest of world. Source: Global Trade Atlas. Color version available online. 


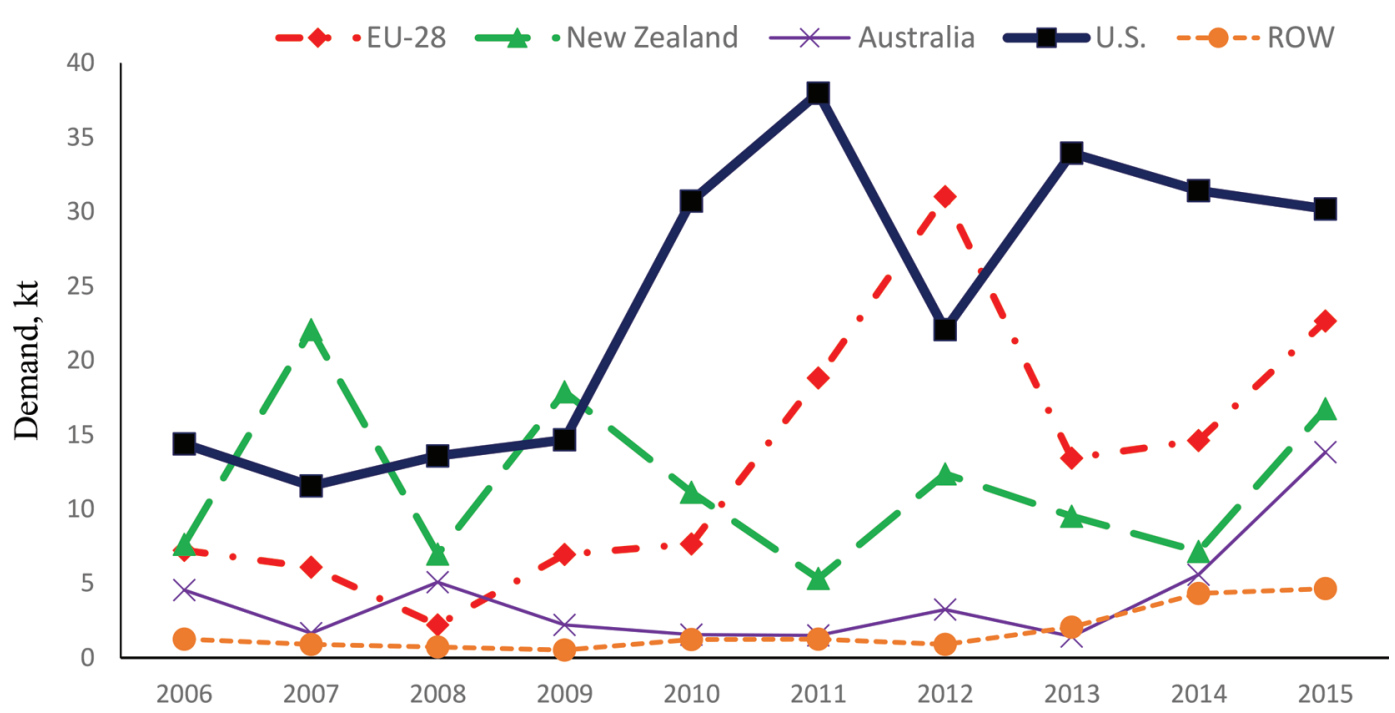

Figure 3. Vietnam's import demand (kilotonnes) for skim milk powder from major suppliers. ROW = rest of world. Source: Global Trade Atlas. Color version available online.

Although SMP is one of the largest dairy products imported by the Philippines, SMP imports grew by less than $1 \%$ from 2006 to 2015 . The US was the largest supplier of SMP to the Philippine market from 2011 to 2015 (Figure 4). However, the Philippine imports of SMP from the EU increased 10-fold, while SMP imports from the US grew 45\%. After the recession period of 2008-2009, the Philippine imports of US SMP increased and continued to climb until 2013. Imports of SMP then fell significantly in 2014 and slightly in 2015.

\section{MATERIALS AND METHODS}

\section{Rotterdam Import Demand Model}

Import demands for SMP were estimated for Vietnam, Indonesia, the Philippines, and Singapore using the Rotterdam modeling framework (Seale et al., 1992). The Rotterdam model is a demand system that works in differentials to estimate consumers' responsiveness to changes in price and expenditure. In this study, we assumed that the import demand for SMP was differentiated by source or exporting country for each of these destinations. The differential approach has been frequently used to estimate import demand (Theil, 1980; Seale et al., 1992; Weatherspoon and Seale, 1995; Mohammad et al., 2012; Seale et al., 2013). According to Seale et al. (1992), the Rotterdam parameterization under the differential approach is useful in estimating the demand for disaggregated imported goods. More details about the Rotterdam model computation can be found in Appendix 1.

Four Rotterdam models were used to analyze SMP import markets, one each for Vietnam, Indonesia, the

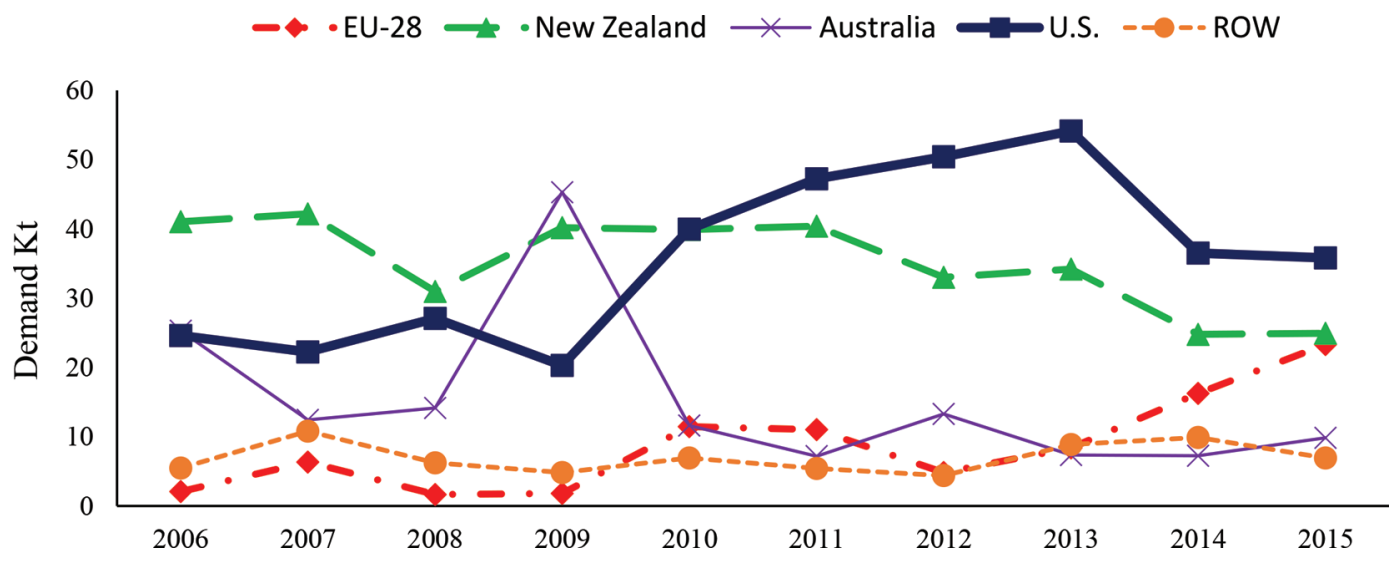

Figure 4. Philippines's import demand (kilotonnes) for skim milk powder from major suppliers. ROW = rest of world. Source: Global Trade Atlas. Color version available online. 
Philippines, and Singapore. The software used is TimeSeries Processor (TSP; TSP International, Palo Alto, CA). Monthly observations from 2006 to 2015 were analyzed for all 4 country sources. Expenditures in this study were defined as the total value of imported SMP for each importing country, and prices were the imported SMP unit values. In this study, the unit values were landed prices for Singapore and Indonesia, but not for Vietnam and Philippines. The unit values for Vietnam were actually export values and unit values from exporting partner countries. The Philippine unit value was recognized as free on board (FOB) price. A discussion of the parameter estimates for each demand system is found in Appendix 2.

\section{Data}

Skim milk powder import quantities, expenditures, and unit values were collected for Singapore, Vietnam, the Philippines, and Indonesia. Monthly data from 2006 to 2015 are taken from the Global Trade Atlas, a secondary source that receives data from primary sources such as Statistics Indonesia, Thai Customs Department, Philippines National Statistics Office, and US Census Bureau Trade Data (Global Trade Atlas, 2016). Because Vietnam does not provide import data, SMP export data from Vietnam's suppliers were used. All values are in US dollars. Unit values are obtained by dividing the value by the quantity. We acknowledge that unit values are not the same as prices, but they are the only available data we can find.

Skim milk powder is traded among World Trade Organization countries under the 6-digit Harmonized System (HS) code 040210. The major SMP suppliers for Singapore, Vietnam, the Philippines, and Indonesia are the EU, New Zealand, Australia, and the US. In the cases of Singapore and the Philippines, remaining imports from minor exporters were aggregated into a rest of the world (ROW) category. For Vietnam and the Philippines, ROW countries were omitted due to several months of zero trade. In situations where there were only a few missing monthly data points, we inserted a 1 for the missing monthly quantity and an average annual unit value to minimize the effect these data have on the parameter estimates. Using these SMP data, price and expenditure elasticities were estimated for each market.

\section{RESULTS AND DISCUSSION}

Elasticity estimates for all 4 Southeast Asian countries are reported in Tables 2, 3, 4, and 5. The compensated demand shows the relationship between the price of a good and the quantity purchased on the assumption that other prices and utility are held constant. Own-price elasticity measures the responsiveness of a percentage change in the quantity demanded caused by a percentage change in price. The own-price elasticity (bold on diagonal in Tables 2-5) is an importing country's percentage change in SMP import quantity demanded from a particular exporter, corresponding to a $1 \%$ change in that exporting country's export price, all other things being equal. Negative signs for ownprice elasticities are consistent with demand theory; holding all else constant, as the price of SMP rises, the quantity demanded of SMP declines.

Cross-price elasticity is an importing country's percentage change in SMP import quantity from a particular country corresponding to a $1 \%$ change in the export price of another country, all else being equal. A positive cross-price elasticity indicates that the SMP imports for one country substitute for another country. A negative elasticity indicates a complementary relationship between 2 countries.

The last column in Tables 2 through 5 show expenditure elasticity estimates. Expenditure elasticity is an exporter's change in quantity of SMP exported to the importing country corresponding to a $1 \%$ change in total import expenditures of SMP by the importing country, all other things being equal. A positive expenditure elasticity value implies that the quantity of good increases as expenditures increases. It is assumed that if expenditures for a good (quantity $\times$ price) increase along with quantities, demand is most likely to be positively associated with expenditure. Conversely, a negative expenditure elasticity implies that the quantity of imported good decreases as expenditures increase.

\section{Indonesia's SMP Market}

Table 2 shows the price and expenditure elasticities for the Indonesia SMP market, derived from the parameters of the Rotterdam model. All 4 of the major dairy exporters have own-price elasticity estimates that were negative and statistically significant, as expected-increases in price decrease the quantity demanded of the product. Thus, negative signs for own-price elasticities are consistent with demand theory: holding all else constant, as the price of SMP rises, the quantity demanded of SMP will decline. The EU, New Zealand, and Australia own-price elasticity estimates suggest strong levels of sensitivity to changes in import price. They were relatively elastic, which means a $1 \%$ increase in the own-price would result in a $>1 \%$ decrease in Indonesia's quantity demanded of SMP from the EU (-1.45), New Zealand (-1.24), and Australia 
Table 2. Indonesia's price and expenditure elasticities (SE in parentheses) for skim milk powder (SMP) imports $(2006-2015)^{1}$

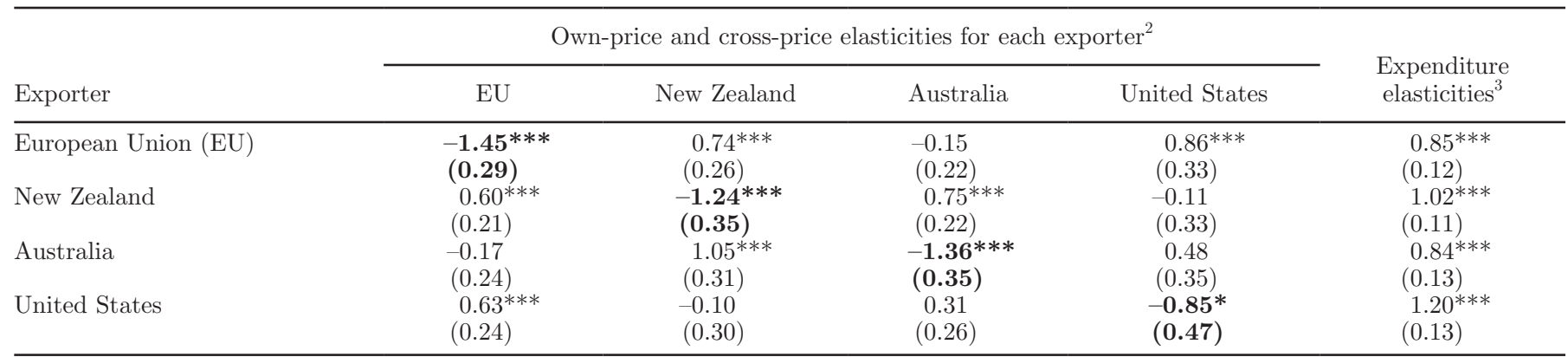

${ }^{1}$ Source: Authors' calculations using the Global Trade Atlas (2016; https://www.gtis.com/gta/).

${ }^{2}$ Own-price elasticity (bold, on diagonal) is an importing country's percentage change in SMP import quantity demanded from a particular exporter corresponding to a $1 \%$ change in that exporting country's export price, all else being equal. Cross-price elasticity (off-diagonal values) is an importing country's percentage change in SMP import quantity from a particular country corresponding to a $1 \%$ change in the export price of another country, all else being equal.

${ }^{3}$ Expenditure elasticity is an exporter's change in quantity of SMP exported to the importing country corresponding to a $1 \%$ change in total import expenditures of SMP by the importing country, all else being equal.

$*=10 \%{ }^{* * *}=1 \%$ level of significance.

(-1.36). However, with an inelastic demand, changes in the price of US SMP would have less of an impact on Indonesia's SMP imports.

Indonesia's cross-price elasticities are shown in the off-diagonals in Table 2 . The value of 0.60 in the second row of the EU column means that a $1 \%$ increase in the price of EU's SMP will cause Indonesia to import $0.6 \%$ $(<1 \%)$ more SMP from New Zealand. This finding suggests that SMP from the EU and New Zealand are substitutes in Indonesia. Of the 12 cross-price elasticities, 6 of the country pairs were statistically significant. Those 6 cross-price elasticities are all substitutes, as indicated by their positive signs. Findings suggest that Indonesians substituted US SMP for EU SMP. A 1\% decrease in the price of US SMP would cause Indonesia to import $0.86 \%$ less EU SMP. Indonesians also substituted New Zealand SMP for EU SMP. Australian SMP was a substitute for New Zealand SMP in Indonesia's marketplace. Substitution relationships are suggested between New Zealand and Australia's SMP. A 1\% increase in the price of New Zealand SMP would result in a $1.05 \%$ increase in Indonesian import of Australia SMP.

All of the expenditure elasticities are positive and statistically significant at the $1 \%$ level, which means that as consumer expenditures for food increase, they will purchase more SMP. New Zealand and US expenditure elasticities were elastic, whereas those for the EU and Australia were inelastic, which means that a $1 \%$ increase in Indonesia's expenditures on SMP will give rise to a $>1 \%$ increase in imported SMP from New Zealand (1.02\%) and the US (1.20\%), but $<1 \%$ increase from the EU (0.85\%) and Australia (0.84\%). Thus, a $1 \%$ change in Indonesia's expenditure on SMP will have a greater impact on US and New Zealand imports than on imports from the EU and Australia. According to our findings, the US stands to benefit more than the other 3 countries if there is an increase in Indonesia's expenditure on SMP.

\section{Singapore's SMP Market}

Price and expenditure elasticities for major suppliers of Singapore's SMP are presented in Table 3. As expected, all suppliers' own-price elasticities were negative and statistically different from zero at the $1 \%$ level. Of the 5 suppliers, SMP imports from the US were the most price sensitive. According to our findings, a $1 \%$ decrease in the import price of US SMP would cause Singapore's import demand to increase by $1.29 \%$. Following the US, the EU stands to gain the most in percentage terms given a $1 \%$ decrease in its SMP price.

Twelve of the 20 cross-price elasticities were statistically significant and all suggest substitute relationships. A $1 \%$ increase in the price of New Zealand's SMP would cause Singapore's import demand for SMP from the EU, Australia, and the US to increase by $0.49,0.35$, and $0.54 \%$, respectively. New Zealand's SMP was also a substitute for the US's SMP in the Singapore market. The same type of substitute relationships exists for New Zealand and the EU, New Zealand and Australia, the US and Australia, the ROW and EU, as well as for the US and ROW in the Singapore market.

All of the expenditure elasticities were positive, as expected, and statistically significant at the $1 \%$ level. The EU, US, and ROW expenditure elasticities were elastic, which means a $1 \%$ change in expenditure on SMP would result in a $>1 \%$ increase in the quantity 
Table 3. Singapore's price and expenditure elasticities (SE in parentheses) for skim milk powder (SMP) imports (2006-2015) ${ }^{1}$

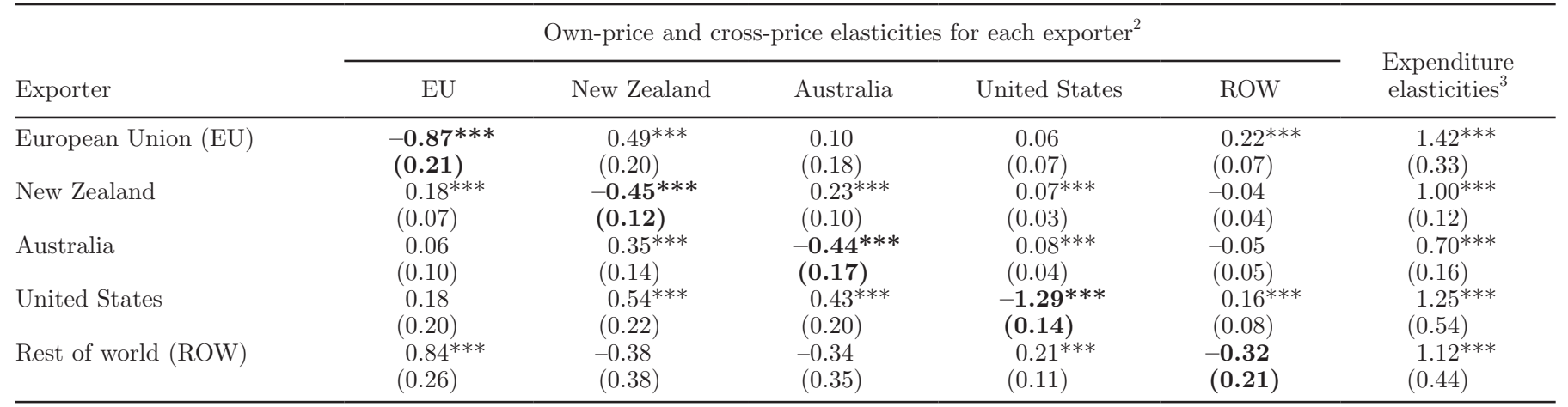

${ }^{1}$ Source: Authors' calculations using the Global Trade Atlas (2016; https://www.gtis.com/gta/)

${ }^{2}$ Own-price elasticity (bold, on diagonal) is an importing country's percentage change in SMP import quantity demanded from a particular exporter corresponding to a $1 \%$ change in that exporting country's export price, all else being equal. Cross-price elasticity (off-diagonal values) is an importing country's percentage change in SMP import quantity from a particular country corresponding to a $1 \%$ change in the export price of another country, all else being equal.

${ }^{3}$ Expenditure elasticity is an exporter's change in quantity of SMP exported to the importing country corresponding to a $1 \%$ change in total import expenditures of SMP by the importing country, all else being equal.

$* * *=1 \%$ level of significance.

imported by Singapore. The expenditure elasticities for New Zealand and Australia were inelastic and not as sensitive to changes in Singapore's expenditure on imported SMP.

According to our findings, the EU stands to benefit more than the other 3 major dairy exporting countries from an increase in Singapore's expenditure on imports of SMP.

\section{Vietnam's SMP Market}

Table 4 shows the price and expenditure elasticities for the Vietnam market. All 4 of the own-price elastici- ties for EU, New Zealand, Australia, and the US had the expected negative sign and were significantly different from zero (at a significance level of 0.01). Demand for EU, New Zealand, and Australia SMP were elastic, with own-price elasticities ranging from -1.38 to -1.89 . Of the 4 major dairy exporters, Vietnam's imports from the US were the least sensitive ( -0.84 elasticity) to changes in import prices of SMP.

The cross-price elasticities of demand for Vietnam's imported SMP are also presented in Table 4. Over $80 \%$ (10 of 12) of the cross-price elasticities were statistically different from zero and positive, suggesting substitute relationships. Skim milk powder from the US served

Table 4. Vietnam's price and expenditure elasticities (SE in parentheses) for skim milk powder (SMP) imports (2006-2015) ${ }^{1}$

\begin{tabular}{|c|c|c|c|c|c|}
\hline \multirow[b]{2}{*}{ Exporter } & \multicolumn{4}{|c|}{ Own-price and cross-price elasticities for each exporter ${ }^{2}$} & \multirow{2}{*}{$\begin{array}{l}\text { Expenditure } \\
\text { elasticities }^{3}\end{array}$} \\
\hline & EU & New Zealand & Australia & United States & \\
\hline New Zealand & $\begin{array}{l}1.12^{* * * *} \\
(0.33)\end{array}$ & $\begin{array}{l}-1.89 * * * \\
(0.40)\end{array}$ & $\begin{array}{c}0.31^{*} \\
(0.16)\end{array}$ & $\begin{array}{l}0.47^{\text {*** }} \\
(0.08)\end{array}$ & $\begin{array}{l}1.43^{* * *} \\
(0.15)\end{array}$ \\
\hline Australia & $\begin{array}{c}0.42 \\
(0.41)\end{array}$ & $\begin{array}{c}0.90^{*} \\
(0.48)\end{array}$ & $\begin{array}{l}-1.67 * * * \\
(0.36)\end{array}$ & $\begin{array}{l}0.36^{* * *} \\
(0.15)\end{array}$ & $\begin{array}{l}1.43^{* * *} \\
(0.28)\end{array}$ \\
\hline
\end{tabular}

${ }^{1}$ Source: Authors' calculations using the Global Trade Atlas (2016; https://www.gtis.com/gta/).

${ }^{2}$ Own-price elasticity (bold, on diagonal) is an importing country's percentage change in SMP import quantity demanded from a particular exporter corresponding to a $1 \%$ change in that exporting country's export price, all else being equal. Cross-price elasticity (off-diagonal values) is an importing country's percentage change in SMP import quantity from a particular country corresponding to a $1 \%$ change in the export price of another country, all else being equal.

${ }^{3}$ Expenditure elasticity is an exporter's change in quantity of SMP exported to the importing country corresponding to a $1 \%$ change in total import expenditures of SMP by the importing country, all else being equal.

$*=10 \% ; * * *=1 \%$ level of significance. 
as a substitute for SMP from other major exporters to Vietnam. Findings suggest that not only is US SMP a substitute for SMP from the EU, Australia, and New Zealand, but these countries' SMP products are also substitutes for US SMP in the Vietnam market. The EU's SMP is a substitute for New Zealand SMP in Vietnam and vice versa. Our findings also suggest that Australia's SMP is a substitute for New Zealand SMP.

Expenditure elasticities for the 4 exporting countries were positive and statistically significant at the $1 \%$ level, suggesting that SMP demand and expenditure were directly related. Most of the exporting countries' expenditure elasticities were elastic in the Vietnam marketplace. The expenditure elasticity for the EU was 1.06; that is, a $1 \%$ increase in Vietnam's expenditures on SMP will give rise to a $1.06 \%$ increase in the quantity of SMP imported from the EU. New Zealand and Australia expenditure elasticities were both 1.43. In contrast to these 3 exporters, the US expenditure elasticity for SMP in the Vietnam market was inelastic; a $1 \%$ increase in Vietnam's expenditures on SMP would have given rise to only a $0.48 \%$ expansion in SMP imports from the US.

\section{The Philippines' SMP Market}

Table 5 displays the price and expenditure elasticities for the Philippines SMP market. Although all the ownprice elasticities were negative, only 3 were statistically significant. Unlike the SMP markets in Vietnam and Indonesia, all of the own-price elasticity estimates were inelastic and would have an impact less than unity in the Philippines given a $1 \%$ change. Of the 3 statistically significant estimates, the demand elasticity for US was largest $(-0.46)$, followed by that of Australia and the EU.

Only 6 of the 20 cross-price elasticity estimates were statistically different from zero. Of these 6,4 were substitutes and 2 were complements. Australian SMP products were substitutes for EU SMP products. In addition, EU SMP products shipped into the Philippines were substitutes for Australia SMP products. Likewise, US SMP was a substitute for the ROW SMP in the Philippines' marketplace and vice versa.

A complementary relationship existed between SMP exports from the EU and the US, and vice versa. Although no definitive reason for this complementary relationship is available from this study, we can think of at least one possibility. Products from the US and the EU are differentiated to some extent. Skim milk powder, as discussed, actually includes both SMP and NDM, 2 very similar products that are not distinguishable in trade data. Protein content for SMP may be adjusted to a specified level, whereas the standard for NDM does not allow for such adjustment (Cessna et al., 2016, Appendix B). Nonfat dry milk is manufactured more than SMP in the US, whereas SMP is manufactured to a greater extent in the EU. For example, a standardized protein level may not be very relevant for consumers who are simply reconstituting the powder with water for drinking milk - a practice common in areas with little refrigeration. In these cases, NDM is acceptable. For certain manufacturing purposes, such as cheese making, where a standardized protein level is desired, SMP may be preferred because it is often standardized to a protein content (34\%) using lactose

Table 5. Philippines's price and expenditure elasticities (SE in parentheses) for skim milk powder (SMP) imports $(2006-2015)^{1}$

\begin{tabular}{|c|c|c|c|c|c|c|}
\hline \multirow[b]{2}{*}{ Exporter } & \multicolumn{5}{|c|}{ Own-price and cross-price elasticities for each exporter ${ }^{2}$} & \multirow{2}{*}{$\begin{array}{l}\text { Expenditure } \\
\text { elasticities }\end{array}$} \\
\hline & $\mathrm{EU}$ & New Zealand & Australia & United States & ROW & \\
\hline New Zealand & $\begin{array}{c}0.01 \\
(0.44)\end{array}$ & $\begin{array}{c}-0.24 \\
(0.16)\end{array}$ & $\begin{array}{l}0.12 \\
(0.10)\end{array}$ & $\begin{array}{c}0.13 \\
(0.10)\end{array}$ & $\begin{array}{c}-0.02 \\
(0.04)\end{array}$ & $\begin{array}{l}1.43^{* * *} \\
(0.13)\end{array}$ \\
\hline Australia & $\begin{array}{l}0.12^{* * * *} \\
(0.04)\end{array}$ & $\begin{array}{c}0.14 \\
(0.12)\end{array}$ & $\begin{array}{l}-0.38^{* * *} \\
(0.12)\end{array}$ & $\begin{array}{c}0.13 \\
(0.80)\end{array}$ & $\begin{array}{c}-0.01 \\
(0.04)\end{array}$ & $\begin{array}{l}0.95^{* * *} \\
(0.12)\end{array}$ \\
\hline Rest of world (ROW) & $\begin{array}{l}-0.07 \\
(0.08)\end{array}$ & $\begin{array}{l}-0.10 \\
(0.21)\end{array}$ & $\begin{array}{c}-0.04 \\
(0.17)\end{array}$ & $\begin{array}{c}0.27^{*} \\
(0.16)\end{array}$ & $\begin{array}{c}-0.06 \\
(0.10)\end{array}$ & $\begin{array}{c}0.27 \\
(0.21)\end{array}$ \\
\hline
\end{tabular}

\footnotetext{
${ }^{1}$ Source: Authors' calculations using the Global Trade Atlas (2016; https://www.gtis.com/gta/).

${ }^{2}$ Own-price elasticity (bold, on diagonal) is an importing country's percentage change in SMP import quantity demanded from a particular exporter corresponding to a $1 \%$ change in that exporting country's export price, all else being equal. Cross-price elasticity (off-diagonal values) is an importing country's percentage change in SMP import quantity from a particular country corresponding to a $1 \%$ change in the export price of another country, all else being equal.

${ }^{3}$ Expenditure elasticity is an exporter's change in quantity of SMP exported to the importing country corresponding to a $1 \%$ change in total import expenditures of SMP by the importing country, all else being equal.

$*=10 \% ; * * *=1 \%$ level of significance.
} 
Table 6. Indonesia imports of skim milk powder (SMP)-estimated impacts ${ }^{1}$ of $10 \%$ reduction in US export price ${ }^{2}$

\begin{tabular}{|c|c|c|c|c|c|c|c|c|c|}
\hline Supplier & \multicolumn{3}{|c|}{ Baseline } & \multicolumn{3}{|c|}{$10 \%$ reduction in US price } & \multicolumn{3}{|c|}{ Difference after reduction } \\
\hline$\overline{\mathrm{EU}-28}$ & 38.88 & 136.05 & 26 & 35.54 & 124.95 & 24 & -3.34 & -11.66 & -2 \\
\hline Australia & 32.34 & 121.71 & 23 & 32.34 & 121.71 & 23 & 0 & 0 & 0 \\
\hline United States & 46.57 & 167.63 & 31 & 50.47 & 163.51 & 32 & 3.9 & -4.12 & 1 \\
\hline
\end{tabular}

${ }^{1}$ Quantity $\times 1,000$ t; value in US\$ million; share in percent.

${ }^{2}$ Source: Authors' calculations using the Global Trade Atlas (2016; https://www.gtis.com/gta/) and results from Rotterdam modeling.

or permeate. Because prices for both products generally move in the same direction and consumption of both products respond in a direction opposite to price, the products may appear to be complements.

Expenditure elasticities were positive and statistically significant for 4 of the 5 major dairy exporting countries. The only elastic expenditure elasticity was for New Zealand. A 1\% increase in the Philippines' expenditures caused its import of New Zealand SMP to increase by $1.43 \%$. As for as the other major dairy exporting markets, any change in the Philippines expenditure would produce a change in imports relatively smaller than the initial change in New Zealand.

\section{Implications for US Exporters}

This report provides some possible insights into the future of the US dairy exports to countries in Southeast Asia. Tables 6, 7, 8, and 9 illustrate the effect of a $10 \%$ reduction in the US export price on Indonesia, Singapore, Vietnam, and the Philippines imported SMP. Tables 6 to 9 show the baseline scenario, results of a $10 \%$ reduction in the US SMP price, and the difference after the reduction in price. In all 4 tables, the baseline was calculated using the average volumes and unit values over the 3 yr (2013-2015). A 10\% reduction in US SMP price was calculated along with the associated impacts on SMP imported from other suppliers. The differences were derived by subtracting the baseline estimates from the estimates calculated using a $10 \%$ reduction in US SMP price. All shares were based on each exporter's percentage of the total value of SMP imported.

In Indonesia, the own-price elasticity for US SMP was inelastic (Table 2). The US and EU SMP are substitutes for each other in the Indonesian market, which implies that there are opportunities for the US to gain more market share in Indonesia through competitive pricing with the EU. According to the calculated baseline, a $10 \%$ decrease in the US export price of SMP would cause Indonesia's import demand of SMP to increase by 3,900 $\mathrm{t}$ (Table 6). However, this reduction in the US export price of SMP would lower US total value of exported SMP by $\$ 4.12$ million. The EU's SMP ex- ports to Indonesia would decrease by $3,340 \mathrm{t}$ and $\$ 11.66$ million in total value (Table 6). We make no inferences about imports from New Zealand or Australia due to a change in the US export price because the associated cross-price elasticities were not found to be statistically significant.

The US accounts for only $6 \%$ of Singapore's imported SMP. However, Singapore is more responsive to changes in the US import price of SMP than it is to those of the EU, New Zealand, or Australian SMP (Table 3). Our findings also suggest that US SMP exports are substitutes for New Zealand and Australia SMP, which could open the door for US competitive pricing of SMP exported to Singapore. Given our estimated baseline, a $10 \%$ reduction in the price of US SMP exports to Singapore would likely increase US SMP exports by $440 \mathrm{t}$ and raise US total SMP export value by $\$ 200,000$ (Table 7 ). The effect of a $10 \%$ reduction in the US SMP price would cause New Zealand and Australia SMP exports to Singapore to drop by 190 and 130 t, respectively, coupled with $\$ 650,000$ and $\$ 560,000$ reductions in total value for these countries, respectively (Table 7). The cross-price elasticities for the US and EU are statistically insignificant, thus no inference is provided.

Our findings showed that Vietnam is more sensitive to changes in the own-price of SMP imported from the EU, New Zealand, and Australia relative to the SMP import price from the US. Most of the SMP imported into Vietnam by the 4 large dairy exporters was presumed to be substitutable within the Vietnam market (Table 4). Given the baseline, a 10\% reduction in the US export price of SMP would increase the amount of US SMP exports to Vietnam by 2,670 t and lower its total SMP export value by $\$ 2.93$ million (Table 8 ). The US SMP exports are substitutes for EU, New Zealand, and Australia SMP in the Vietnamese market. Relative to our baseline, a $10 \%$ price reduction in US SMP exports is expected to cut exports of SMP from the EU, New Zealand, and Australia to Vietnam by 600 , 520 , and 250 t, respectively (Table 8 ). In addition, the total values of SMP exported by the EU, New Zealand, and Australia are expected to decline by $\$ 2.13$ million, $\$ 1.60$ million, and $\$ 0.72$ million, respectively (Table 
Table 7. Singapore imports of skim milk powder (SMP)-estimated impacts ${ }^{1}$ of $10 \%$ reduction in US export price ${ }^{2}$

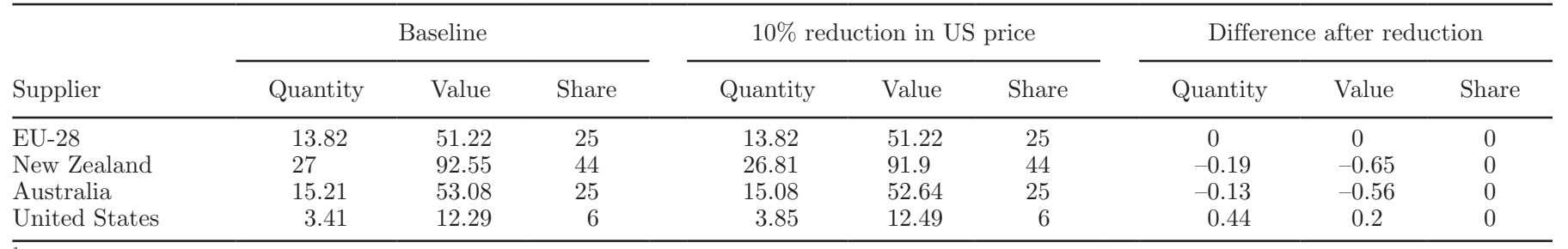

${ }^{1}$ Quantity $\times 1,000$ t; value in US $\$$ million; share in percent.

${ }^{2}$ Source: Authors' calculations using the Global Trade Atlas (2016; https://www.gtis.com/gta/) and results from Rotterdam modeling.

8). These substitution relationships create possible opportunities for the US to compete with the EU, New Zealand, and Australia in competitive pricing to gain more of Vietnam's SMP market share.

In the Philippine dairy import market, the EU, Australia, and US own-price elasticities are inelastic; that is, not very responsive to changes in price (Table 5). Considering the baseline estimates, if the US were to lower its export price of SMP by 10\%, the Philippines would import 1,950 t more US SMP; however, the total value of SMP imports from the US would decrease by 2,480 $\mathrm{t}$ (Table 9). The US SMP serves as a complement to the EU's SMP in the Philippine market and vice versa (Table 5). Once again, given the baseline, a $10 \%$ reduction in US SMP exports would result in a $420-\mathrm{t}$ increase in EU's SMP exports to the Philippine with a value of $\$ 1.06$ million (Table 9 ). No inferences are made for New Zealand or Australia due to their insignificant cross-price elasticities.

Now, assume a $10 \%$ reduction in the price of New Zealand's SMP exports to Indonesia, Singapore, Vietnam, and the Philippines. What would likely happen to US SMP exports to these importing countries as a result of a $10 \%$ reduction in New Zealand SMP export price? Given the same baseline for the US and New Zealand reported in Tables 6 through 9, New Zealand SMP exports to Indonesia, Singapore, and Vietnam would increase by $3,370,1,200$, and 2,110 t over the baseline estimates (Table 10). Notice that no inference is made for EU due to its insignificant cross-price elasticity. New Zealand's total values of SMP exports to
Indonesia and Vietnam increased by $\$ 1.27$ million and $\$ 2.41$ million, respectively.

Given that the US SMP is a substitute for New Zealand's SMP in Singapore and Vietnam, a 10\% reduction in the price of SMP exported by New Zealand would cause US SMP exports in Singapore and Vietnam to drop by 440 and 1,220 t, respectively (Table 10). The cross-price elasticities for New Zealand and the US are insignificant in Indonesia and the Philippines. The total values of US SMP exports to Singapore and Vietnam would fall. Overall, the US would export more SMP to Indonesia, Vietnam, and the Philippines than New Zealand if New Zealand SMP exports were to decline by $10 \%$.

What if all of the SMP suppliers - the EU, New Zealand, and Australia - decided to incorporate the same strategy the US used and lower their SMP prices by $10 \%$ for Indonesia, Singapore, Vietnam, and the Philippines? Because we imposed homogeneity (defined as "uniform in structure or composition"; see Appendix 1) on the model, the demand function is homogeneous of degree zero in prices and expenditures such that all own-price and cross-price elasticities are equal to its expenditure elasticities (Phlips, 1974). If the US manufacturers were to sell SMP at a lower price, then US gains in trade volumes would not be realized if all other exporters lowered their prices by the same percentage. Thus, a proportionate change on all prices has no impact on the import allocation across exporting countries. The share proportions would remain the same as the baseline estimates.

Table 8. Vietnam imports of skim milk powder (SMP)-estimated impacts ${ }^{1}$ of $10 \%$ reduction in US export price ${ }^{2}$

\begin{tabular}{|c|c|c|c|c|c|c|c|c|c|}
\hline \multirow[b]{2}{*}{ Supplier } & \multicolumn{3}{|c|}{ Baseline } & \multicolumn{3}{|c|}{$10 \%$ reduction in US price } & \multicolumn{3}{|c|}{ Difference after reduction } \\
\hline & Quantity & Value & Share & Quantity & Value & Share & Quantity & Value & Share \\
\hline New Zealand & 11.15 & 34.18 & 15 & 10.63 & 32.58 & 14 & -0.52 & -1.60 & -1 \\
\hline Australia & 6.95 & 20.25 & 9 & 6.7 & 19.53 & 9 & -0.25 & -0.72 & 0 \\
\hline United States & 31.85 & 117.74 & 50 & 34.52 & 114.81 & 51 & 2.67 & -2.93 & 1 \\
\hline
\end{tabular}

${ }^{1}$ Quantity $\times 1,000 \mathrm{t}$; value in US\$ million; share in percent.

${ }^{2}$ Source: Authors' calculations using the Global Trade Atlas (2016; https://www.gtis.com/gta/) and results from Rotterdam modeling. 
Table 9. Philippine imports of skim milk powder (SMP)-estimated impacts ${ }^{1}$ of $10 \%$ reduction in US export price ${ }^{2}$

\begin{tabular}{|c|c|c|c|c|c|c|c|c|c|}
\hline Supplier & \multicolumn{3}{|c|}{ Baseline } & \multicolumn{3}{|c|}{$10 \%$ reduction in US price } & \multicolumn{3}{|c|}{ Difference after reduction } \\
\hline EU-28 & 15.99 & 39.63 & 24 & 16.41 & 40.69 & 24 & 0.42 & 1.06 & 0 \\
\hline Australia & 8.14 & 40.80 & 24 & 8.14 & 40.80 & 24 & 0 & 0 & 0 \\
\hline United States & 42.16 & 42.38 & 25 & 44.11 & 39.90 & 25 & 1.95 & -2.48 & -1 \\
\hline
\end{tabular}

${ }^{1}$ Quantity $\times 1,000$ t; value in US $\$$ million; share in percent.

${ }^{2}$ Source: Authors' calculations using the Global Trade Atlas (2016; https://www.gtis.com/gta/) and results from Rotterdam modeling.

\section{General Discussion}

Rising purchasing power, changing consumption patterns, urbanization, and modest population growth are expected to increase dairy product consumption in Southeast Asia in the future. Given the need for local milk production to serve the growing demand for fluid products, the region is likely to continue to import manufactured milk products such as SMP in the long term (Ang, 2016; Wright and Darmawan, 2016). Although imported SMP faces little or no competition from domestic production in the selected countries, there is competition from other ingredients (such as whey or soy protein products) used in manufacturing products for final demand by consumers (Wright and Darmawan, 2016). Thus, the price of SMP relative to other products will continue to be important in determining future import levels. Furthermore, because SMP is a relatively homogeneous product, the findings of this analysis suggest there is vigorous price competition among SMP export suppliers in certain cases.

Most of the recent US growth in exports has been to Asian importers, where domestic dairy production has been exceeded by domestic demand. In the last $5 \mathrm{yr}$, Asia has been the destination for almost $40 \%$ of US dairy exports, and most of the US dairy exports to Southeast Asia have been SMP. Some of the major US SMP destinations include Vietnam, the Philippines, and Indonesia. The USDA Agricultural Projections to 2025 indicate that economic growth is likely to be strong for Southeast Asia over the next decade (USDAOCE, 2016). Thus, there are opportunities for the US to increase SMP exports to these countries. As expenditure and population growth continue in Southeast Asia, expenditures on SMP are expected to increase. According to our findings, the US is expected to benefit more from an increase in expenditures in Indonesia and Singapore than it would from increased expenditures in Vietnam and the Philippines. However, US market share will also depend on price competition with other major dairy exporters.

For each country, we used a $10 \%$ price-reduction scenario for US SMP to illustrate how the US could improve its position as one of the world's major SMP suppliers. For Singapore, a 10\% reduction in the US price resulted in greater revenue for US firms because demand is elastic - a $10 \%$ reduction in price leads to an increase of more than $10 \%$ in the quantity demanded. The changes for an increase in the US price are the opposite of those shown for a reduction. The US own-price elasticities in Indonesia, Vietnam, and the Philippine are inelastic $(<1)$, which means that consumers are not as sensitive to a price increase in those 3 countries as they are in Singapore. In other words, a $10 \%$ increase in the US export SMP price would give rise to $<10 \%$ decrease in Indonesia, Vietnam, and the Philippines' import demand of US SMP.

Despite the importance of Southeast Asia as a destination for US SMP exports, the potential effectiveness of US strategic pricing is quite limited, given that each

Table 10. Southeast Asia imports of skim milk powder (SMP)-estimated impacts (quantity and value) on United States given a 10\% reduction New Zealand (NZ) export price ${ }^{1}$

\begin{tabular}{|c|c|c|c|c|c|c|c|c|}
\hline Importer & \multicolumn{2}{|c|}{ Quantity, $\times 1,000 \mathrm{t}$} & \multicolumn{2}{|c|}{ Value, US\$ millions } & \multicolumn{2}{|c|}{ Quantity, $\times 1,000 \mathrm{t}$} & \multicolumn{2}{|c|}{ Value, US $\$$ millions } \\
\hline Singapore & 27.0 & 28.20 & 92.54 & 87.02 & 3.41 & 2.97 & 12.29 & 10.70 \\
\hline Vietnam & 11.15 & 13.26 & 34.18 & 36.59 & 31.86 & 30.64 & 117.74 & 113.23 \\
\hline Philippines & 27.96 & 27.96 & 46.21 & 46.21 & 42.16 & 42.16 & 42.38 & 42.38 \\
\hline
\end{tabular}

${ }^{1}$ Source: Authors' calculations using the Global Trade Atlas (2016; https://www.gtis.com/gta/) and results from Rotterdam modeling. 
firm makes its own pricing decisions. For example, if a particular firm raises its price by $10 \%$ for customers in Indonesia, Vietnam, or the Philippines, management of the firm cannot expect revenue to necessarily increase simply because demand for US exports of SMP to those countries is inelastic. That firm faces competition from firms included in this analysis, ROW countries not specifically analyzed in this study, and other US firms. The unique circumstances of each firm and its customers determine the responses to pricing strategies of the firm. Even if all of the US firms changed export prices in tandem, price changes by firms of other countries, as well as other global circumstances, may counteract some of the effects shown in this analysis.

In addition to changes in price, other variables such as expenditure and population growth in Southeast Asia are expected to increase expenditures on SMP. According to our findings, the US is expected to benefit more from an increase in expenditures in Indonesia and Singapore than it would from an increase Vietnam and the Philippine.

\section{ACKNOWLEDGMENTS}

The opinions and analysis presented represent the authors' ideas and do not necessarily reflect those of Economic Research Service or the US Department of Agriculture's position.

\section{REFERENCES}

Ang, P. 2016. Dairy and products annual, Philippines. USDA Foreign Agricultural Service GAIN report 1610. Accessed Jan. 24, 2017.
https://gain.fas.usda.gov/Recent\%20GAIN\%20Publications/ Dairy\%20and\%20Products\%20Annual_Manila_Philippines_10-13 -2016.pdf.

Attfield, C. L. F. 1985. A homogeneity and endogeneity in systems of demand equations. J. Econom. 27:197-209.

Barten, A. P. 1964. Consumer demand functions under conditions of almost additive preferences. Econometrica 32:1-38.

Cessna, J., L. Kuberka, C. G. Davis, and R. Hoskin. 2016. Growth of U.S. dairy exports, LDPM-270-01. USDA, Economic Research Service. Accessed Jan. 24, 2017. https://www.ers.usda.gov/ publications/pub-details/?pubid $=81251$.

Global Trade Atlas. 2016. Global Trade Atlas database. IHS Markit, London, UK.

Mohammad, A., L. L. McPhail, and J. Kiawu. 2012. Do U.S. cotton subsidies affect competing exporters? An analysis of import demand in China. J. Agric. Appl. Econ. 44:235-249.

Phlips, J. 1974. Applied Consumption Analysis. Elsevier Science Ltd., Amsterdam, North Holland.

Seale, J. L., A. L. Sparks, and B. M. Buxton. 1992. A Rotterdam application to international trade in fresh apples: A differential approach. J. Agric. Resour. Econ. 17:138-149.

Seale, J. L., L. Zhang, and M. R. Traboulsi. 2013. U.S. import demand and supply response for fresh tomatoes, cantaloupe, onions, oranges, and spinach. J. Agric. Appl. Econ. 45:435-452.

Theil, H. 1965. The information approach to demand analysis. Econometrica 33:67-87.

Theil, H. 1980. The System-Wide Approach to Microeconomics. The University of Chicago Press, Chicago, IL.

USDA-OCE (Office of the Chief Economist). 2016. USDA agricultural projections to 2025. Accessed Jan. 30, 2017. https://www .ers.usda.gov/webdocs/publications/37809/56729_oce-2016-1.pdf $? \mathrm{v}=42508$

Weatherspoon, D. D., and J. L. Seale Jr. 1995. Do the Japanese discriminate against Australian beef imports? Evidence from the differential approach. J. Agric. Appl. Econ. 27:536-543.

Wright, T., and B. Darmawan. 2016. Indonesia 2016 dairy and products annual report. USDA Foreign Agricultural Service GAIN report ID1629. Accessed Jan. 25, 2017. https://gain.fas.usda.gov/ Recent\%20GAIN\%20Publications/Dairy\%20and\%20Products\%20 Annual_Jakarta_Indonesia_10-17-2016.pdf.

\section{Appendix 1: The Rotterdam Model}

The Rotterdam model is specified as follows:

$$
\bar{w}_{i t} D q_{i t}=\theta_{i} D Q_{t}+\pi_{i j} \sum_{j=1}^{n} D p_{j t}+\varepsilon_{i t},
$$

where $\bar{w}_{i t}$ is the share value of total imports of SMP from country $i$ in time $t ; D$ is the log difference operator where, for any variable $z, D z_{t}=\log \left(z_{t}\right)-\log \left(z_{t-1}\right) ; q_{i}$ is the quantity of SMP from country $i$; and $p_{j}$ is the price of SMP in country $j ; \theta_{i}$ is the marginal share of the $i$ th good, which is the additional amount spent on SMP imports from country $i$ when total SMP imports increase by $\$ 1 ; D Q_{t}$ is a finite-change version of the Divisia volume index, where $D Q_{t}=\sum_{j=1}^{n} \bar{w}_{i t} D q_{i t} ;$ and $\pi_{i j}$ is the $(i, j)$ th Slutsky coefficient of the Rotterdam model, and $\varepsilon_{i t}$ is the error term for country $i$ in time $t$. The $n \times n$
Slutsky matrix $\left[\pi_{i j}\right]$ is symmetric negative semidefinite of rank $n-1$, resulting in the following restrictions: $\sum_{j=1}^{n} \pi_{i j}=0$ (homogeneity) and $\pi_{i j}=\pi_{j i}$ (symmetry).

In this study, 4 models were estimated for SMP imports in Vietnam, Indonesia, the Philippines, and Singapore. Compensated demand elasticities for all $4 \mathrm{im}-$ porting countries are expressed as such: $\frac{\% \Delta q_{i t}}{\% \Delta p_{j}}=\pi_{i j} / \bar{w}_{j}$ and $\frac{\% \Delta q_{i t}}{\% \Delta E x p}=\theta_{i} / \bar{w}_{i}$, where Exp is the total SMP expenditure for country $i, \pi_{i j} / \bar{w}_{j}$ represents the compensated price elasticities, and $\theta_{i} / \bar{w}_{i}$ represents the compensated expenditure elasticities. One of the demand equations was dropped from the demand systems to avoid singularity (Attfield, 1985). 
Table A1. Indonesia-derived demand parameter estimates (SE in parentheses) for imported skim milk powder (SMP) by source ${ }^{1}$

\begin{tabular}{|c|c|c|c|c|}
\hline Imported SMP & $\mathrm{EU}$ & New Zealand & Australia & United States \\
\hline European Union (EU) & $\begin{array}{l}-0.32^{* * *} \\
(0.07)\end{array}$ & $\begin{array}{l}0.16^{* * *} \\
(0.04)\end{array}$ & $\begin{array}{c}-0.03 \\
(0.05)\end{array}$ & $\begin{array}{l}0.19^{* * *} \\
(0.07)\end{array}$ \\
\hline New Zealand & & $\begin{array}{l}-0.34 * * * \\
(0.10)\end{array}$ & $\begin{array}{l}0.21^{* * *} \\
(0.06)\end{array}$ & $\begin{array}{l}-0.04^{* * *} \\
(0.09)\end{array}$ \\
\hline Australia & & & $\begin{array}{l}-0.27^{* * *} \\
(0.07)\end{array}$ & $\begin{array}{c}0.10 \\
(0.08)\end{array}$ \\
\hline United States & & & & $\begin{array}{c}-0.26^{*} \\
(0.14)\end{array}$ \\
\hline
\end{tabular}

${ }^{1}$ Source: Authors' calculation using the Global Trade Atlas (2016; https://www.gtis.com/gta/).

$*=10 \% ; * * *=1 \%$ level of significance.

\section{Appendix 2: The Rotterdam Model Parameter Estimates}

Parameter estimates for all 4 Southeast Asian countries are reported in Appendix Tables A1, A2, A3, and A4. These parameter estimates were derived directly from the 4 import demand models and were then used to derive the various elasticity estimates. All of the own-price parameters (along the diagonal) for the 4 countries are negative and statistically significant except for ROW's SMP in Singapore and New Zealand's SMP in the Philippines. As expected, all of the crossprice parameters are positive, indicating substitution among the 4 importing countries with the exception of the complementary relationship that exists in the Philippine market for US and EU SMP. With the ex- ception of the ROW, all of the expenditure elasticities are positive and are statistically significant.

Using these parameter estimates, we are able to derive the compensated demand elasticities that appear in Appendix Tables A1 through A4. The compensated demand shows the relationship between the price of a good and the quantity purchased, on the assumption that other prices and utility are held constant. In the Results and Discussion, and the Implications for US Exporters sections, we discuss the own-price, crossprice, and expenditure elasticities for the 4 Southeast Asian countries.

Table A2. Singapore-derived demand parameter estimates (SE in parentheses) for imported skim milk powder (SMP) by source

\begin{tabular}{|c|c|c|c|c|c|}
\hline \multirow[b]{2}{*}{ Imported SMP } & \multicolumn{4}{|c|}{ Exporting countries } & \multirow[b]{2}{*}{ ROW } \\
\hline & $\mathrm{EU}$ & New Zealand & Australia & United States & \\
\hline European Union (EU) & $\begin{array}{l}-0.14^{* * *} \\
(0.04)\end{array}$ & $\begin{array}{l}0.08^{* * *} \\
(0.03)\end{array}$ & $\begin{array}{c}0.02 \\
(0.03)\end{array}$ & $\begin{array}{c}0.01 \\
(0.01)\end{array}$ & $\begin{array}{l}0.04^{* * *} \\
(0.01)\end{array}$ \\
\hline New Zealand & & $\begin{array}{l}-0.20^{* * *} \\
(0.06)\end{array}$ & $\begin{array}{l}0.10^{* * *} \\
(0.04)\end{array}$ & $\begin{array}{c}0.03^{*} \\
(0.01)\end{array}$ & $\begin{array}{c}-0.02 \\
(0.02)\end{array}$ \\
\hline Australia & & & $\begin{array}{l}-0.13^{* * *} \\
(0.05)\end{array}$ & $\begin{array}{l}0.02^{* * *} \\
(0.01)\end{array}$ & $\begin{array}{c}-0.02 \\
(0.02)\end{array}$ \\
\hline United States & & & & $\begin{array}{l}-0.07^{* * *} \\
(0.01)\end{array}$ & $\begin{array}{l}0.01^{* * *} \\
(0.00)\end{array}$ \\
\hline Rest of world (ROW) & & & & & $\begin{array}{c}-0.01 \\
(0.01)\end{array}$ \\
\hline
\end{tabular}

${ }^{1}$ Source: Authors' calculation using the Global Trade Atlas (2016; https://www.gtis.com/gta/).

$*=10 \% ; * * *=1 \%$ level of significance. 
Table A3. Vietnam-derived demand parameter estimates (SE in parentheses) for imported skim milk powder (SMP) by source ${ }^{1}$

\begin{tabular}{|c|c|c|c|c|}
\hline \multirow[b]{2}{*}{ Imported SMP } & \multicolumn{4}{|c|}{ Exporting country } \\
\hline & $\mathrm{EU}$ & New Zealand & Australia & United States \\
\hline European Union (EU) & $\begin{array}{l}-0.45^{* * *} \\
(0.09)\end{array}$ & $\begin{array}{l}0.30 * * * \\
(0.09)\end{array}$ & $\begin{array}{c}0.04 \\
(0.04)\end{array}$ & $\begin{array}{c}0.11 \\
(0.07)\end{array}$ \\
\hline New Zealand & & $\begin{array}{l}-0.50^{* * *} \\
(0.11)\end{array}$ & $\begin{array}{c}0.08^{*} \\
(0.04)\end{array}$ & $\begin{array}{l}0.12^{* * *} \\
(0.02)\end{array}$ \\
\hline Australia & & & $\begin{array}{l}-0.15^{* * *} \\
(0.03)\end{array}$ & $\begin{array}{l}0.03^{* * *} \\
(0.01)\end{array}$ \\
\hline United States & & & & $\begin{array}{l}-0.27^{* * *} \\
(0.01)\end{array}$ \\
\hline
\end{tabular}

${ }^{1}$ Source: Authors' calculation using the Global Trade Atlas (2016; https://www.gtis.com/gta/).

$*=10 \% ; * * *=1 \%$ level of significance.

Table A4. Philippines-derived demand parameter estimates (SE in parentheses) for imported skim milk powder (SMP) by source ${ }^{1}$

\begin{tabular}{lccccc}
\hline & \multicolumn{4}{c}{ Exporting country } \\
\cline { 2 - 4 } Imported SMP & $\mathrm{EU}$ & New Zealand & Australia & United States & ROW \\
\hline European Union (EU) & $-0.02^{* * *}$ & 0.01 & $0.04^{* * *}$ & $-0.02^{*}$ & -0.01 \\
& $(0.01)$ & $(0.02)$ & $(0.01)$ & $(0.01)$ & $(0.01)$ \\
New Zealand & & -0.09 & 0.04 & 0.05 & -0.01 \\
& & $(0.06)$ & $(0.04)$ & $(0.04)$ & $(0.02)$ \\
Australia & & $-0.12^{* * *}$ & $0.04^{*}$ & -0.00 \\
& & $(0.04)$ & $(0.02)$ & $(0.01)$ \\
United States & & & $-0.09^{* * *}$ & $0.02^{*}$ \\
Rest of world (ROW) & & & & $(0.03)$ & $(0.01)$ \\
& & & & $-0.43^{* * *}$ \\
& & & & $(0.01)$ \\
\hline
\end{tabular}

${ }^{1}$ Source: Authors' calculation using the Global Trade Atlas (2016; https://www.gtis.com/gta/).

$*=10 \% ; * * *=1 \%$ level of significance. 